\title{
Bokanmeldelse
}

Harald Grimen: Hva er tillit. Universitetsforlaget, 2009. 151 sider.

\section{Tillitens mange ansikter}

Uten tillit ville ikke mennesket kunne forlate sin seng om morgenen, hevdet sosiologen Niklas Luhmann. Allikevel er det langt ifra klart hva vi snakker om når vi snakker om tillit. Noen mener til og med at tillit bare fins når det $i k k e$ er nødvendig å snakke om det. Med et slikt filosofisk limbo er det mer enn gledelig at Universitetsforlaget har bedt professor Harald Grimen om å redegjøre for fenomenet tillit i deres «Hva er»-serie. Ikke bare fordi han er Norges fremste ekspert på temaet; hans tilnærming til problemet - den handlingsteoretiske - er også helt avgjørende for at det har lyktes ham å skrive en bok hvor et vanskelig håndgripelig fenomen vristes ut av teorienes eiegode favntak og ut i lysningen, hvor vi kan se både teoriene og fenomenet $i$ en ganske uregjerlig, men meningsgivende sammenheng. Grimen viser oss den enorme bredden i litteraturen om tillit, viser oss eksempler som forteller oss noe annet enn det vi trodde på foregående side, og peker på hvordan teorier har en tendens til å forelske seg i bestemte empiriske eller teoretiske antakelser, og at de derfor kjører seg fast i stivnet virkelighet. Prisen for en slik åpenhet mot virkelighetens omskiftelighet er som alltid vanskeligheten med å etablere et sterkt teoretisk fundament som kan stå seg som egen teori. Så langt er det ingen teorier om tillit som formår å gjøre dette på en fyllestgjørende måte. Grimen er en beskjeden mann og ydmyk på sin boks vegne i dette henseendet, men det må være lov å si at han kommer ganske langt i å risse opp konturene av en teori som også tar høyde for virkelighetens egenart og sære oppførsel. Selv om han tar med seg handlingsteoriens metodiske forutsetninger inn i boka, er han varsom med å trekke for bastante slutninger, og han virker mer opptatt av å vise til empiri som forteller oss det motsatte av hva han nettopp har fortalt enn å falle i samme felle som de teoretikerne han refererer til. Det handlingsteoretiske perspektivet er heller ikke en absolutt forklaringsmodell for begrepet tillit, men det er en bedre tilnærmingsmåte enn alternativene, sier Grimen, fordi å forstå måter å handle på i stedet for motivene bak handlingen, gjør det lettere å forstå forbindelsene mellom tillit, makt og sårbarhet (s. 134). Samtidig er det stadig mulig å integrere motivasjonsaspekter for å bidra til å forstå hvorfor mennesker handler som de gjør. Grimen er som en oppdagelsesreisende som peker og forklarer, men som varsomt lar menneskenaturen tale sitt tilsynelatende uregjerlige språk, og som hele tiden viser hvor det er de forskjellige teoriene på markedet kjører seg fast eller låser seg inne. Det siste er viktig, for begrepet tillit ledsages med Grimens ord av en «definisjonsoverflod» 
som gjør det vanskelig å skjelne mellom hva vi vet og hva vi ikke vet. En teori som forsøker å bestemme tillit ut fra bestemte forutsetninger, kommer ikke bare til kort når virkeligheten spenner bein for den. Perspektivet stenger også andre perspektiver ute, og gjør det vanskelig å se de mange teoriene som annet enn forklaringsmodeller bundet opp til enkelte empiriske eller teoretiske forutsetninger, som måner til planeter, og som ikke har blikk for den store sammenhengen. Skal vi komme til større klarhet, er det derfor helt avgjørende at vi går inn til selve kjernen av hver teori for å se hva som gjør at den velger ett bestemt perspektiv, og hva som gjør at den ender opp med ikke å kunne komme utover dette perspektivet.

Tillit og mistillit er komplekse fenomener som har vakt stadig økende oppmerksomhet de seinere åra. Tillit sies å være et smøremiddel for samhandling, mens andre påpeker hvor viktig mistillit kan være for det samme. Andre igjen bruker begrepet som en nøkkel for å forstå oss selv i en tid hvor rask endring flytter grensene for vår selvforståelse, og hvor vi i stadig større grad bruker refleksiviteten for å opprettholde en fortrolighet med våre omgivelser. Grimen henviser til sosiologen Anthony Giddens, som hevder at i det moderne samfunnet er tillit et «trossprang» som skal gjenopprette den fortroligheten mellom enkeltmennesker og samfunnet som gikk tapt med det førmoderne småsamfunnet, hvor makten var absolutt, og hvor fremmede var som marsboere. Stoler vi eller stoler vi ikke på at verdens myndigheter tar klimaspørsmålet alvorlig? Er klimaspørsmålet i det hele tatt det problem som ekspertene sier? Når er det bra å ha mistillit, og når er den bare til besvær for en god fordøyelse? Når må vi selv vite, og når kan vi overlate til andre å ta vare på vår egen sikkerhet? Giddens peker på noe viktig når han hevder at tillit er et moderne fenomen som får aktualitet i møtet med former for risiko som tidligere var ukjent. Tillit blir et kognitivt begrep i den forstand at vi bruker vår refleksivitet for å markere grensene for hva vi føler vi må vite, og hva vi kan overlate til andre å ha styring over. Men å hevde at tillit derfor er et trossprang, fører til, som Grimen gjør oppmerksom på, at det ikke lenger er mulig å skille mellom irrasjonell og rasjonell tillit. Flere teorier tar utgangspunkt $i$ at tillit bygger på tillitsgiveres varierende grad av kunnskap om tillitsmottakeres pålitelighet. Jo mer kunnskap, desto mer rasjonell er tilliten. Problemet med slik kognitivisme, hevder Grimen, er at den gjør det irrasjonelt å stole på noen vi vet lite om, og den benekter at det er mulig å møte andre mennesker med naturlig tillit, slik for eksempel den danske filosofen og teologen K. E. Løgstrup hevder at vi gjør. For ham er tilliten et helt tilgrunnforliggende trekk ved menneskets møte med andre. Tillit er «en mulighedsvedligeholdende mulighed» (s. 90) som åpner handlingsrom der hvor mistillit er et hinder for det samme. Dette normative aspektet ved tillit har utvilsomt mye for seg. Bakeren Eddie Eidsvåg ble i sin tid berømt for mer enn sin bror da han tok i mot unge fengselsfugler som lærlinger og gav dem en sjanse som mange tok imot ved å ta ansvar for sitt liv. 
Men selv om studier viser at mange mennesker er tilbøyelig til å stole på personer de ikke kjenner, varierer dette fra land til land og fra krig til fred. Grimen ser begge posisjoner som uttrykk for at for sterke empiriske antakelser er bygd inn i teorien (s. 36). Hos Løgstrup blir det normative begrunnet i en empirisk antakelse som lar det normative bli stående utenfor virkeligheten selv. Derfor blir mistillit også stående som en motsetning som er uforenlig med tillit. «Lade der være måde med ens tillid [...] er ugørligt, i samme nu er man i mistilliden», sier Løgstrup (1996: 25). Men en skal være utstyrt med en god porsjon tiltro til hinsidig belønning for å se det hensiktsmessige $i$ et moralsk fundert tillitsbegrep som gjør en konstant utsatt for misbruk noe den som har fulgt Baasland-saken nok kan (eller burde?) nikke gjenkjennende til. ${ }^{1}$ Dessuten vil begrepet bli helt meningsløst når det kommer til forholdet mellom enkeltindivider og institusjoner. Eller som Grimen så elegant formulerer det: «Løgstrup tilhørte en tradisjon hvor 'Den Annen' omtales i entall og med stor forbokstav. Hvis man ser at flertall og små bokstaver også er mulig, får man et annet blikk på tillit og mistillit.» (s. 98).

Både Niklas Luhmann og Harald Grimen viser til at tillit og mistillit kan utfylle hverandre i mange sammenhenger. Luhmann påpeker at selv om tillit og mistillit strukturelt sett er ulike, hvor den ene er funksjonell og den andre dysfunksjonell, så kan de begge funksjonelt sett føre til økt tillit. Godtroenhet overfor samfunnsinstitusjoner kan lett føre til situasjoner hvor det slett ikke er noen grunn til å ha tillit. Og maktfordelingsprinsippet - som forutsetter at en ikke kan stole på at maktutøvere kan operere uten tilsyn, er kanskje det beste eksempelet på at systematisert mistillit kan være et virkningsfullt grep for å fremme tillit i henhold til en funksjonalistisk forståelse av begrepet. Luhmann skiller mellom personlig og upersonlig mistillit. Jeg ble en gang fortalt at da Norges statsminister Gunnar Knudsen og hans bror skulle gjøre opp boet etter sine foreldre, valgte de å ikke involvere kostbare advokater, men delte arven etter følgende formel: Den ene deler, den andre velger. Dette behøver ikke å være et uttrykk for personlig mistillit, men kan like gjerne ses på som en virksom måte å sikre seg mot at det personlige tillitsforholdet skal settes unødig på prøve. Allerede Thomas Hobbes var inne på at vi kan sove trygt fordi andre er våkne for oss.

Tillit åpner handlingsrom. Når vi stoler på legen, åpner vi for at denne skal kunne bruke sin kunnskap til å helbrede oss. Vi kan nedbygge skepsis - og dermed berede grunnen for samhandling - gjennom «de små skritts metode» (s. 76). Eller vi kan gjøre som den egyptiske presidenten Anwar Sadat, som risikerte både sitt politiske liv og sitt eget da han reiste til Israel i 1978 og la grunnen for den viktige fredsavtalen mellom de to landene (s. 78). Men dette - altså virkninger av tillit - forstås ifølge Grimen best i sammenheng med makt. «Analyser av tillit som utelater makt, er naive. Analyser av makt som utelater tillit, er grunne», skriver han (s. 53). Tillit skaper rom for maktutø- 
velse, og det gjør tillitsgivere sårbare. Å vise tillit kan i gitte situasjoner føre til pålitelighet dersom angjeldende person er avhengig av det.

Makt og tillit kan forstås som både indre og ytre forbindelser. I amerikaneren Russell Hardins teori om «innbefattede interesser», som Grimen på mange måter har stor sans for, er det tillitsmottakerens pålitelighet med hensyn til egeninteresse som legges til grunn for vurderingen av dennes tillitsverdighet: Det er rasjonelt å stole på noen man vet deler ens interesser. Hardin antar at tillit oppstår i gjentatt samhandling, og på samfunnsmessig nivå kan gjensidig tillit mellom ellers ukjente mennesker framdyrkes ved interessefellesskap. Men også her blir forutsetningen i Grimens øyne for kognitivistisk. Den avviser for eksempel at en kan ha tillit til vilt fremmede mennesker, og teorien blir for snevert knyttet til bestemte motiver hos tillitsgiveren, og gjør det vanskelig å diskutere forholdet mellom makt og tillit. I relasjoner med åpenbart skeiv maktfordeling er det like lite trolig å forvente at den sterke part skal ta hensyn til den svake, som det er at den avmektige vil handle annerledes på mistillit enn på tillit. Fordi makt og tillit dermed ensidig forstås som ytre forbindelser, blir det i Hardins teori umulig å ha tillit til institusjoner, for maktforholdet mellom institusjonen og den enkelte gjør det ufornuftig å stole på den.

For Grimen er det et grunnleggende krav til en fullstendig teori om tillit at den ikke bare må forklare hva tillit er, en må også tilstrebe å kunne forutsi når tillitsgivere gjør som de gjør, og hvorfor. I Grimens handlingsteoretiske tilnærming til fenomenet er det i forholdsreglene - eller i mangelen på dem - at en best kan forstå tillitens vesen. I Franz Kafkas novelle «Hiet» (Der Bau) møter vi et dyr som bor i et underjordisk hi med én utgang. Dyret føler seg trygt og sover godt om natta, men en ubestemmelig lyd skaper bekymring og får det til å grave en flukttunnel. Men én nødutgang er ikke nok, den nagende bekymringen får dyret til å utvikle et stadig mer intrikat nett av fluktveier og foranstaltninger. Til slutt er hiet så uoverskuelig at alle inn- og utgangene vender seg mot sin skaper, og blir en trussel i seg selv. Grimen bruker denne novellen som et sinnbilde på hvordan velmente forholdsregler kan vende seg mot sin hensikt. Forholdsregler som er ment å skulle holde andre ute, kan fort komme til å holde en selv innesperret. Likeledes kan det som er ment å skulle beskytte, komme til å signalisere mistro overfor andre. Handlingsteoretisk er tillit ikke forventninger, men måter å handle på, sier Grimen (s. 134). Samtidig er det klart at forventningene som går forut for tillitsgiveres handlinger, kan bidra til å forstå hvorfor de tar forholdsregler. En slik tilnærmingsmåte er bedre enn alternative inngangsmåter, for den gjør det lettere å forklare forbindelser mellom tillit, makt og sårbarhet, og dermed også begrepet selv. Dessuten unngår man å måtte binde seg til én type motiver som forklaring på alle uttrykk for tillit.

Noen tar det for gitt at det må være et mål for samfunnets lykke at folk stoler på sine politikere. Uavhengige observatorer påpekte imidlertid etter siste valg at det norske valgsystemet var for preget av tillit. Tillit handler 
således både om refleksjon, om makt og om samhandling. Men forsøk på å bestemme hva den er, tar ofte ikke høyde for at tillit opptrer forskjellig i forskjellige kulturer og samfunn, betinget av deres forskjellige historie som gjør at mennesker innretter seg på forskjellig vis.

Grimen tar utgangspunkt $i$ at tillit ikke først og fremst er en holdning eller en oppfatning, men et treleddet forhold: Noen stoler på noen med henblikk på noe. Jeg kan stole på at min venn betaler tilbake det han skylder, men jeg stoler ikke på at han kommer presis til vår avtale i dag. Å ha tillit til noen på dette viset er å handle med få forholdsregler, sier Grimen og låner en tanke fra filosofen Jon Elster. En slik tilnærming bygger på det Grimen kaller svak kognitivisme, som tillater behandling av mange fenomener som sterkere kognitivisme lukker for. Svak kognitivisme kjennetegnes ved at den tar høyde for at tillitsgiveres handlinger avhenger av deres forventninger om tillitsmottakerne, og rasjonaliteten i disse handlingene er betinget av hvordan de forholder seg til sin viten. Det er irrasjonelt å stole på noen man vet er upålitelig, men det er ikke nødvendigvis irrasjonelt å stole på noen man vet lite om.

Grimen medgir at denne bokas lille format gjør det umulig å dekke alle forhold hvor tillit og mistillit gjør seg gjeldende, og antyder problemstillinger som han vil kunne vende tilbake til seinere. Det ser jeg fram til med utålmodighet. Selv innenfor den begrensede tumleplassen han har hatt til rådighet her (151 sider), har han allerede vist et langt større overblikk over fenomenene tillit og mistillit enn jeg har sett noen andre steder. Spennet i teoretiske problemstillinger og den rikdommen av eksempler han kommer med, overgår langt det jeg har vært inne på her, og hans evne til å formidle det hele på en lettfattelig måte er intet mindre enn imponerende. Boka anbefales derfor på det varmeste.

Trond Åm, NTNU

\section{Litteratur}

Løgstrup, K. E. (1996) Etiske begreber og problemer. København: Gyldendal

\section{Noter}

1 Baasland-saken ble kjent høsten 2008, da det kom fram at Stavanger-biskopen Ernst Baaslands sønn, Bjarte Baasland, hadde fått sine foreldre til å låne et tosifret antall millioner kroner fra banker, venner og bekjente på vegne av sønnens angivelige forretningsdrift. Det viste seg at det meste hadde gått med til gambling på Internett. Ekteparet ble begjært konkurs, og biskopen måtte trekke seg fra sitt embete som følge av saken. I tillegg ble fru Bodhild Baasland tiltalt for bedrageri. 